\title{
The effects of electromagnetic and electrostatic fields on the development and yield of greenhouse tomato plants
}

\author{
ZOFIA WIEWIÓRKA
}

\begin{abstract}
Institute of Botany, Wrocław University, Department of Plant Ecology and Nature Protection, ul. Kanonia 6/8, 50-328 Wroctaw, Poland
\end{abstract}

(Received: March 16, 1987)

\begin{abstract}
The effects of electromagnetic and electrostatic fields on tomato plants (in potted and hydroponic culture) were investigated. The broad-band, noisy character continuous spectrum electromagnetic field (with an intensity from 20 to $500 \mathrm{~V} / \mathrm{m}$, frequency from $1 \mathrm{~Hz}$ to $30 \mathrm{MHz}$ ) and electrostatic field (with an intensity of 2,2 to $46,5 \mathrm{kV} / \mathrm{m}$ ) used in the experiments stimulated the tomato yield, height and biomass of plants. The differences in the character of the electromagnetic and electrostatic fields were reflected in the various optimal intensities for tomato yield, height and biomass of plants. Characteristic reactions of tomato plants to the electrostatic and electromagnetic fields were also found. The electromagnetic field had a greater effect on tomato yield in the case of plants cultivated in post in comparison with plants cultivated in hydroponic cultures. Electromagnetic and electrostatic fields with specific parameters may by used for growth stimulation of plants cultivated in greenhous.
\end{abstract}

\section{INTRODUCTION}

Information about experiments on the effects of electric energy on the growth and development of plants was becoming available concomitantly with the spreading of the science of electricity in the 18 th century. Th o m p k i n s et al. (1975) gave a detailed description of the now historical studies of various experimentors and professional researchers.

The first observations on the effect of natural electromagnetic fields on plants were made by L e $\mathrm{m} \mathrm{s} t \mathrm{r}$ ö $\mathrm{m}$ (1904). This researcher showed that the lush 
the electromagnetic radiation during the northern lights and not by the length of the summer day as had been thought to then. He found that the annual growth rings of pine trees correlated with the periods of high nortern lights and sun spot activities. According to $\mathrm{L} u \mathrm{n}$ d (1947) the intensity of natural electromagnetic fields is too low to affect the metabolism of plants, whereas B u r r (1975) found after many year-long studies that there is a dependence between the electrical potentials of trees and the electromagnetic activity of the external environment. He discovered strict correlations between the activity of sun spots, geomagnetic activity, moon cycles and the 27-day-long earth's cycles discovered by him and the electrical potentials of trees.

The natural electromagnetic environment of the earth encompasses a wide range of radiation from constant electric and magnetic fields to high energy ionizing radiation with frequencies of $10^{24} \mathrm{~Hz}$. Atmospheric radio noises also belong to the natural phenomena in the earth's atmosphere, being one of the many effects of storm discharges. Solar electromagnetic and cosmic radiation of specific frequency ranges are also considered to be noise.

The combined effects of all of the natural electromagnetic phenomena in the atmosphere give a broad-band continuous spectrum ( $R$ o t k i e w i c z, 1978).

The effect of electromagnetic radiation of radio frequencies from $3 \times 10^{3}$ to $3 \times 10^{12} \mathrm{~Hz}$ on plants has not been understood well yet. The studies done to date have been limited to the choice of specific frequencies: M i 11 e r et al. (1976, 1980, 1983), M u r r (1966) to the frequency of $60 \mathrm{~Hz}, \mathrm{~N}$ o s o l (1984) to $50 \mathrm{~Hz}$. Preliminary studies on the effect of broad-band electromagnetic fields of a noisy nature and continuous spectrum in the range of radio waves on ecological populations of Lemna minor L. (W i e w i ó $\mathrm{r} \mathrm{k}$ a, 1986) and Ricciocarpus natans and Riccia flutans (S a r o s i e k and W i e w i ó r k a, 1986) have shown that this factor has a significant effect on the growth and development of plants.

On the other hand, studies on the effect of electrostatic fields on plants are well known. A significant effect of electrostatic fields on the morphogenesis of plants and changes of the polarity of ions inside plants has been found. The roots of plants bend in the direction of the anode when they are in an electrostatic filed (B r o o k s, 1941; L u n d, 1947). Many studies have been devoted to the effects of electrostatic fields on the seeds of many species of plants. D a b r o w s k i (1981), M a the s et al. (1969), S h a p o v a l ov (1979) have demonstrated the stimulating effect of an electrostatic field (in a specified range of parameters of this field) on germination ability and increase of yields.

Manipulation with electric fields makes it possible to take adventage of the properties of cell membranes to create new types of cells with new traits 
(Z i m merm an n et al., 1981).

The results of studies of the effects of electromagnetic and electrostatic fields on plants are rather ambiguous, and in some cases, even contradictory in the assessment of their effect. The vagueness and methodological shortcomings which can be found in reports on this subject make it difficult or even impossible to compare their results.

This study has undertaken to compare the effect of an electromagnetic field of a noisy character, broad-band and continuous spectrum, and for comparison, of and electrostatic field on the development and yield of tomatoes. In addition, it is discussed whether the differences in the effects of the electromagnetic and electrostatic fields concern only the effectivity of the reaction or if there are reactions characteristic to each of the fields. The question if the eventual stimulatory effects of the fields can be made of use in horticulture is also raised.

\section{MATERIALS AND METHODS}

The experiment was conducted in the greenhouse of the Wroclaw University Botanical Garden in three variants:

a) tomatoes grown in hydroponic culture were subjected to an electromagnetic field,

b) tomatoes grown in hydroponic culture were subjected to an electrostatic field,

c) tomatoes grown in pots were subjected to an electromagnetic field.

Tomato seedlings of an average height of $16,5 \mathrm{~cm}$ were planted on June 24 in hydroponic containers and pots. In the hydroponic variant, two-part hydroponic containers were used according to $\mathrm{G} \mathrm{u} \mathrm{m}$ i ń s $\mathrm{k}$ a et al. (1975). The lining was made from a mixture of peat with brown coal from Turoszów. The volume ratio of peat to coal was $2: 1$. The $\mathrm{pH}$ of the medium was maintained at approximately 6,5 by adding sulfuric acid or sodium hydroxide as needed. The level of the medium was maintained at an appropriate level throughout the experiment. In the potted variant the plants were planted in $32 \mathrm{~cm}$ diameter pots filled with a mixture of the following composition: 3 parts of hotbed soil, 3 parts dung soil, 2 parts peat, 1 part sand. The plants in this variant were watered with tap water throughout the experiment. The experiment was conducted in 6 repetitions.

The following equipment was used to generate the electric fields:

a) the source of the constant voltage was a $220 \mathrm{~V}$ line voltage tripler constructed according to P a w lo w s k i (1980). The output voltage was $930 \mathrm{~V}$. The 
measured voltage of the hum of frequency of $50 \mathrm{~Hz}$ and of the nearest harmonic oscillation can be neglected in comparison with the output voltage of the feeder cable due to applying peak rectification and the high effective resistance of the load. The internal electric resistance of the feeder cable was $1 \mathrm{M}$, which protected from electric shock during work in case of accidental touching of live parts of the feeder cable. This type of feeder was also chosen because of the simplicity of its construction, ease in assembling it, availability of parts and reliability.

b) a broad-band alternating current generator with a continuous spectrum and noisy character. The electromagnetic field with a noisy character, continuous spectrum and broad-band was obtained using a broad-band alternating current generator with a continuous spectrum and noisy character $(P$ a w $ł$ o w s k i, 1980). The spectrum of the frequency of the output voltage of the system was measured with a Bruel \& Kjaer type 21-20 Frequency Analyser and equaled from $1 \mathrm{~Hz}$ to $30 \mathrm{MHz}$. The resultant effective voltage of the noise was $9 \mathrm{~V}$. A broadband digital voltmeter, the type 24-27 Autoranging Digital Voltmeter from Bruel $\&$ Kjaer was used to measure this value. The calibration of this voltmeter for measuring noise was checked with a standard noise generator. The equipment and all of the measurements were made with the help and under the direction of a team from the Design Office of the Research and Development of Broadcasting Receptin of the "Diora" Radio Works in Dierżoniów.

c) arrangement of electrodes. The upper electrode was made using an isolated copper wire streched over a wooden frame measuring $100 \times 300 \mathrm{~cm}$. The wire was fastened to pegs as shown on Figs. 1 and 2. This method guarantees that the electrode acts like a uniform metal sheet and fulfills at the same time a very important condition of the experiment, that is, does not limit the access of light. The construction of the electrode with a low inductance, according to the above diagram permits the uniform distribution of the electric field, especially along the long axis where the studied cultures were placed. This is especially important at the highest frequencies of the radiated band in the experiments with the electromagnetic field. In order to provide identical experimental conditiond, identical upper electrodes were used in the experiments with the electrostatic and electromagnetic fields and in the control samples, except that in the latter case, a string with the same cross section as the wire was used. In all of the experiments the lower electrode was a metal plate. The electrodes were connected by the shortest possible wires to the appropriate radiation generators. The pots with the studied plants or the hydroponic containers were placed in the electrostatic field of the condensor which, as one of its covers had the upper electrode placed above the plants, and the other was a grounded metal plate under the pots or hydroponic 
containers (lower electrode). The upper electrode was connected to the positive pole of the direct current generator. The negative pole of the feeder was grounded (Fig. 1).

In the variant with the electromagnetic field the plants were placed in the field of an electromagnetic condensor made as above with an upper electrode and grounded lower electrode. The electrodes were connected to the appropriate terminals of an alternating current generator as shown on Fig. 2.

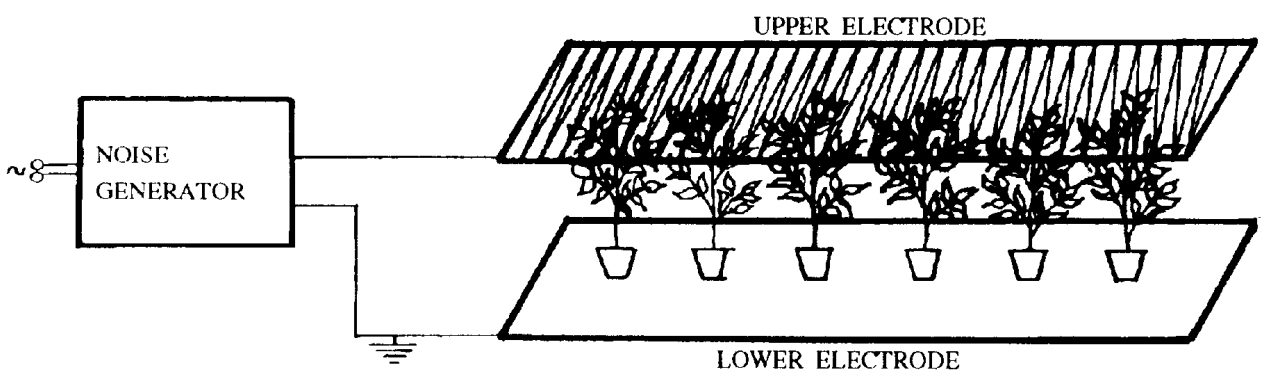

Fig. 1. Electrical configuration in the experiment with the electrostatic field

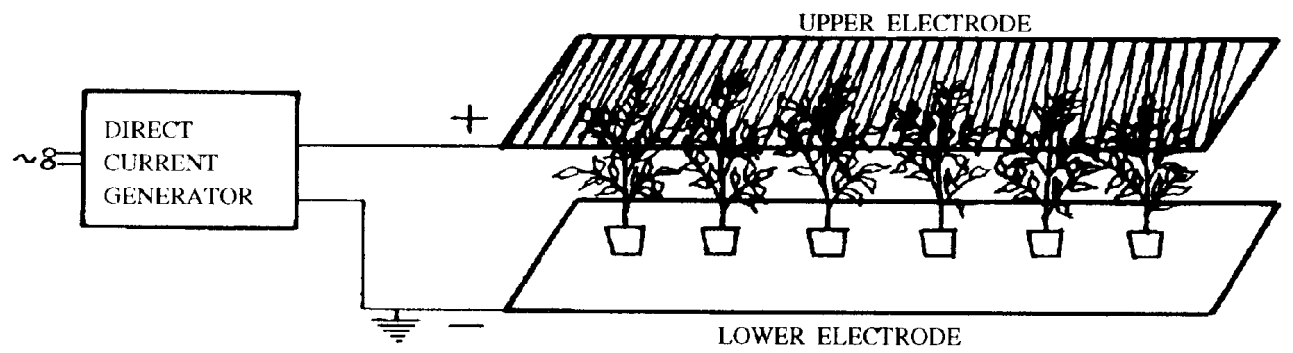

Fig. 2. Electrical configuration in yhe experiment with the electromagnetic field

The intensities of the electromagnetic and electrostatic fields were differentiated as follows: 23,$8 ; 83,3$ and $500 \mathrm{~V} / \mathrm{m}$ and 2,$2 ; 7,7$ and $46,5 \mathrm{kV} / \mathrm{m}$, respectively.

The determination of the distribution of an electric field in a natural environment is, generally speaking, a complicated problem. That is why in this study it was attempted to use an emmission system allowing the intensity of the emitted electric field to be determined in the simplest way possible. In trying to achieve the highest uniformity of the field, the system of flat electrodes described above was used and the intensity of the field was calculated using the following formula:

E - the intensity of the electric field,

$$
\mathrm{E}=\frac{\mathrm{U}}{\mathrm{d}} \quad \text { where: }
$$

$\mathrm{U}$ - the voltage between the covers of the flat condensor,

$\mathrm{d}$ - the distance between the upper electrode and the tip of the plant 


\section{RESULTS}

The influence of electromagnetic and electrostatic fields on the studied plants was evaluated on the basis of their biological effect,manifested in the differences between the tested and control plants in how rapidly they fruits appeared, dry weight of the plants, their height and weight of the fruits.

In experiments on Lemna minor L. (W i e w i ó $\mathrm{k}$ a, 1986) and on Ricciocarpus natans and Riccia flutans ( $\mathrm{S}$ a r o s i e k, W i e w i o r k a, 1986) the exposition doses, threshold intensities of the electromagnetic field, $20 \mathrm{~V} / \mathrm{m}$ and $2 \mathrm{kV} / \mathrm{m}$ of the electrostatic field, were established. Fields having lesser intensities did not evoke any growth reactions.

The first flower developed after 31 days in the electrostatic field of the lowest intensity. After an additional week the greatest number of flowering plants was in the variant subjected to the electromagnetic field in potted culture. The control plants in both potted and hydroponic culture developed more slowly. After yet another week, all of the plants an the potted culture, both those subjected to the electromagnetic field as well as the controls, were flowering. Fewer plants bloomed in hydroponic culture subjected to the electrostatic and electromagnetic fields as well as controls.

The plants in potted culture subjected to the electromagnetic fields began to develop fruit earlier. The control plants in potted culture also began to develop fruit earlier than the hydroponic controls. The plants in hydroponic culture subjected to the electrostatic field had more fruits starting to develop when compared to the same stage of plants subjected to the electromagnetic field in hydroponic culture.

The electromagnetic field showed a greater effect on the yield of tomatoes in potted culture than on that of tomatoes in hydroponic culture. The lowest applied intensity of the electromagnetic field $(20 \mathrm{~V} / \mathrm{m})$ gave the greatest increase in yield both in potted culture (by $54 \%$ ) and in hydroponic culture (by $15 \%$ ). The strongest electromagnetic field $(500 \mathrm{~V} / \mathrm{m})$ had a limiting effect on the increase in fructification, height of plants and fresh and dry weight of the plants in potted culture (Tables 1, 2, 3 and 4). However, the highest dry weight in potted culture was found at this field intensity ( $19 \%$ ). Table 6 contains data on the number of small, unripe fruit which were not allowed to mature because it was necessary to quickly terminate the experiment. The number of fruits in potted and hydroponic cultures differed only slightly (Table 5). The greatest stimulation in the electrostatic field was found with the strongest field, $46,5 \mathrm{kV} / \mathrm{m}$. The plants gave the highest yield (by $16 \%$ ) and the greatest fresh weight (also greater by $16 \%$ ) in this field, while 
distinctly having the lowest dry weight (Tables 1, 3 and 4). Variation of the intensity of the electrostatic field showed only an insignificant effect on the height of the plants and the number of fruits (Tables 2 and 5).

Table I

The influence of electric fields on the yield of tomatoes

\begin{tabular}{|c|c|c|c|c|}
\hline \multicolumn{5}{|c|}{ Yield $(\mathrm{g})$} \\
\hline \multicolumn{3}{|c|}{ Electrmagnetic field } & \multicolumn{2}{|c|}{ Electrostatic field } \\
\hline $\begin{array}{c}\text { Intensity } \\
\mathrm{V} / \mathrm{m}\end{array}$ & $\begin{array}{l}\text { Hydroponic } \\
\text { culture }\end{array}$ & $\begin{array}{l}\text { Potted } \\
\text { culture }\end{array}$ & $\begin{array}{c}\text { Intensity } \\
k \mathrm{~V} / \mathrm{m}\end{array}$ & $\begin{array}{c}\text { Hydroponic } \\
\text { culture }\end{array}$ \\
\hline Control & 1318,7 & 1260,1 & Control & 1318.7 \\
\hline 23,8 & 1516.5 & 1950,6 & 2,2 & 1323,7 \\
\hline 83,3 & 1417,6 & 1795,6 & 7.7 & 1481,6 \\
\hline 500,0 & 1374,0 & 1750,0 & 46,5 & 1542,0 \\
\hline Mean & 1406,7 & 1689.0 & Mean & 1416.3 \\
\hline LSD 0,05 & 40,7 & 31,3 & LSD 0.05 & 37,9 \\
\hline
\end{tabular}

Table 2

The influence of electric fields on the height of plants

\begin{tabular}{|c|c|c|c|c|}
\hline \multicolumn{5}{|c|}{ Height (cm) } \\
\hline \multicolumn{3}{|c|}{ Electromagnetic field } & \multicolumn{2}{|c|}{ Electostatic field } \\
\hline $\begin{array}{c}\text { Intensity } \\
\mathrm{V} / \mathrm{m}\end{array}$ & $\begin{array}{l}\text { Hydroponic } \\
\text { culture }\end{array}$ & $\begin{array}{l}\text { Potted } \\
\text { culture }\end{array}$ & $\begin{array}{c}\text { Intensity } \\
\mathrm{kV} / \mathrm{mI}\end{array}$ & $\begin{array}{l}\text { Hydroponic } \\
\text { culume }\end{array}$ \\
\hline Control & 89.3 & 88,3 & Control & 89.3 \\
\hline 23,8 & 111,2 & 100.0 & 2.2 & 96,8 \\
\hline 83,3 & 95.6 & 102,0 & 7.7 & 98.1 \\
\hline 500.0 & 104,3 & 98.8 & 46,5 & 97,0 \\
\hline Mean & 101.1 & 97,2 & Mean & 95,3 \\
\hline LSD 0.05 & 4.7 & - & LSD 0.05 & 2,6 \\
\hline
\end{tabular}

Table 3

The influence of electric fields on biomass

\begin{tabular}{|c|c|c|c|c|}
\hline \multicolumn{4}{|c|}{ Biomass $(\mathrm{g})$} & \multicolumn{2}{|c|}{ Electrostatic fields } \\
\hline $\begin{array}{c}\text { Intensity } \\
\text { V/m }\end{array}$ & $\begin{array}{c}\text { Hydroponic } \\
\text { culture }\end{array}$ & $\begin{array}{c}\text { Potted } \\
\text { culture }\end{array}$ & $\begin{array}{c}\text { Intensity } \\
\mathrm{kV} / \mathrm{ml}\end{array}$ & $\begin{array}{c}\text { Hydroponic } \\
\text { culture }\end{array}$ \\
\hline & & & & \\
Control & 180,8 & 250.3 & Control & 180.8 \\
23,8 & 224.8 & 254.8 & 2.2 & 206.7 \\
83,8 & 219.5 & 256.5 & 7.7 & 195.0 \\
500.0 & 214,6 & 252.8 & 46.5 & 211.3 \\
& & & & 198.4 \\
\hline Mean & 209,9 & 253.6 & Mean & \\
LSD 0.05 & 7,1 & N.S. & LSD 0.05 & 8.2 \\
\hline
\end{tabular}


Table 4

The influence of electric fields on dry weight

\begin{tabular}{|c|c|c|c|c|}
\hline \multicolumn{5}{|c|}{ Dry weight $(g)$} \\
\hline \multicolumn{3}{|c|}{ Electromagnetic field } & \multicolumn{2}{|c|}{ Electrostatic field } \\
\hline $\begin{array}{c}\text { Intensity } \\
\mathrm{V} / \mathrm{m}\end{array}$ & $\begin{array}{l}\text { Hydroponic } \\
\text { culture }\end{array}$ & $\begin{array}{l}\text { Pottled } \\
\text { culture }\end{array}$ & $\begin{array}{c}\text { Intensity } \\
\mathrm{kV} / \mathrm{m}\end{array}$ & $\begin{array}{l}\text { Hydroponic } \\
\text { culture }\end{array}$ \\
\hline Control & 31,3 & 35.9 & Control & 31,1 \\
\hline 23,8 & 37.2 & 39.7 & 2.2 & 38.3 \\
\hline 83,3 & 35.0 & 40.0 & 7.7 & 32,7 \\
\hline 500,0 & 32.2 & 46.0 & 46.5 & 31.1 \\
\hline Mean & 33,8 & 40,4 & Mean & 33.3 \\
\hline LSD 0.05 & 1.1 & 1.1 & LSD 0.05 & 0.6 \\
\hline
\end{tabular}

Table 5

The influence of electric fields on the number of fruits

\begin{tabular}{|c|c|c|c|c|}
\hline \multicolumn{5}{|c|}{ Number of fruits (n) } \\
\hline \multicolumn{3}{|c|}{ Electromagnetic field } & \multicolumn{2}{|c|}{ Electrostatic field } \\
\hline $\begin{array}{c}\text { Intensity } \\
\mathrm{V} / \mathrm{m}\end{array}$ & $\begin{array}{c}\text { Hydroponic } \\
\text { culture }\end{array}$ & $\begin{array}{l}\text { Potted } \\
\text { culture }\end{array}$ & $\begin{array}{c}\text { Intensity } \\
\mathrm{kV} / \mathrm{m}\end{array}$ & $\begin{array}{c}\text { Hydroponic } \\
\text { culture }\end{array}$ \\
\hline Control & 7,8 & 8,1 & Control & 7.8 \\
\hline 23,8 & 7,6 & 8,5 & 2,2 & 10.3 \\
\hline 83,3 & 9,5 & 9,3 & 7.7 & 10,1 \\
\hline 500,0 & 10,1 & 9.8 & 46,5 & 10.5 \\
\hline Mean & 8,7 & 8.9 & Mean & 9.6 \\
\hline LSD 0.05 & 0,9 & 0.7 & LSD 0.05 & N.S. \\
\hline
\end{tabular}

Ta ble 6

The influence of electric fields on the unripe of fruits

\begin{tabular}{|c|c|c|c|c|}
\hline \multicolumn{5}{|c|}{ Number of unripe fruits (n) } \\
\hline \multicolumn{3}{|c|}{ Electromagnetic field } & \multicolumn{2}{|c|}{ Electrostatic field } \\
\hline $\begin{array}{c}\text { Intensity } \\
\mathrm{V} / \mathrm{m}\end{array}$ & $\begin{array}{l}\text { Hydroponic } \\
\text { culture }\end{array}$ & $\begin{array}{l}\text { Polted } \\
\text { culture }\end{array}$ & $\begin{array}{c}\text { Intensity } \\
\mathrm{kV} / \mathrm{m}\end{array}$ & $\begin{array}{c}\text { Hydroponic } \\
\text { culture }\end{array}$ \\
\hline Control & 8.5 & 1.8 & Control & 8.5 \\
\hline 23.8 & 8,5 & 4,0 & 2.2 & 10,3 \\
\hline 83,3 & 9.5 & 5.3 & 7.7 & 11,3 \\
\hline 500,0 & 10,1 & 5,1 & 46,5 & 10,6 \\
\hline Mean & 9.1 & 4.0 & Mean & 10.1 \\
\hline LSD 0,05 & 0,8 & N.S. & LSD 0.05 & 0.8 \\
\hline
\end{tabular}


Qualitative changes were also found to have occurred under the influence of the applied electric fields. The surface of the leaves of plants subjected to the electromagnetic field was greater in comparision with the controls, while in the electrostatic field it was reduced and the leaves were distinctly more lobed than the controls. The green color of the plants subjected to the electrostatic field was significantly darker than that of the controls and plants subjected to the electromagnetic field.

\section{DISCUSSION}

The conducting of such experiments on tomato plants is substantiated by the fact that from the biological point of view, the factor acting on a plant is an electromagnetic or electrostatic field which induces changes in the electrical processes occurring in biological systems. The reactions of plants on an individual level are the manifestations of this factor's actions. Such manifestations were also found in this study.

The growth reactions of plants to electric fields are related to the active flow of an electric current through a plant. According to M u r r (1966), the flow of a current of $10^{-16} \mathrm{~A} / \mathrm{cm}^{2}$ does not cause measureable physiological reactions of plants. A current of $10^{-15}-10^{-9} \mathrm{~A} / \mathrm{cm}^{2}$ stimulates plant growth, which is confirmed by the results of this study. At the same time, a current of $10^{-8}-10^{-6} \mathrm{~A} / \mathrm{cm}^{2}$ inhibits plant growth and causes reduction of dry weight. A current over $10^{-1} \mathrm{~A} / \mathrm{cm}^{2}$ damages leaves and plants.

The average value of a natural electric field ranges from 100 to $130 \mathrm{~V} / \mathrm{m}$ (F e y $\mathrm{n} \mathrm{m}$ a $\mathrm{n}, 1971$ ). Free electric charges (ions) are found in the air. These charges arise due to the ionization of the gaseous atmosphere by cosmic radiation. Ions of significantly greater diameters are the effects of atmospheric pollution. Due to the action of the electric field, the above-mentioned ions are in motion thereby creating an electric current reaching the earth. The measured intensity of this current is very small, only from 3 to $10 \times 10^{-16} \mathrm{~A} / \mathrm{cm}^{2}$. In the experiments carried out in this study, an electrostatic field with three intensities from 2,2 to $46,5 \mathrm{kV} / \mathrm{m}$, was used. The greatest achieved current density between the electrodes was 450 times greater than the current density in a natural electric field of $100 \mathrm{~V} / \mathrm{m}$ and equalled $(1,39-4,65) 10 \mathrm{~A} / \mathrm{cm}^{2}$.

Developmental disturbances, especially growth inhibition, or even its stimulation in low intensity electric fields, can occur due to changes in the system of growth regulators. B r a t t o n et al, (1977) and M o r r i s (1980) have 
demonstrated that electric fields do affect the transport and distribution of growth hormones in tomatoes. According to Bratton, an increase in an electric current over the values of the natural currents of a plant may selectively change the level of IAA and proxidase in tomato tissues. These same authors report that nonionizing radiation stimulates the formation of free radicals, just as in the case of ionizing radiation. M i 11 e r et al. (1976) did not find any abnormalities in chromatin after constant exposition of plants to a low frequency, $75 \mathrm{~Hz}$ and $10 \mathrm{~V} / \mathrm{m}$, electromagnetic field. Damage to plants in the form of diseased leaves, chlorosis or growth inhibition occurs in electromagnetic fields of an intensity from 0,2 to $0,5 \mathrm{x}$ $x 10^{3} \mathrm{kV} / \mathrm{m}$ and frequency of $60 \mathrm{~Hz}$, while the same is found in an electrostatic field of an intensity of $100 \mathrm{kV} / \mathrm{m}$ (M u r r, 1963, 1966).

The qualitative and quantitative changes obtained in the tomato plants in this experiment are probably the effects of changes in their morphogenesis. The various speeds in which flowering and fruiting occurred in plants subjected to electric fields support the conclusion set forth above. It cannot be ruled out that the long exposition of the plants may have caused chromatin abnormalities, thus the changes in the shapes of the leaves of the plants in the electrostatic field or the increased leaf surface of the plants in the electromagnetic field.

When looking for analogies in the mechanism by which both of these types of fields act on plants one should first of all take into consideration the same energetic effects which can stimulate or inhibit specific metabolic processes. The electrodes were fixed at the same heights when the intensities of the electrostatic and electromagnetic fields were increased. The broad-band, continuous spectrum and noisy in nature electromagnetic field is undoubtedly a more effective factor than the electrostatic field. The greatest increase in the weight of fruits, which are the basic object of tomato cultivation, was achieved at the lowest value of the electromagnetic field (Table 1).

The electric fields used in the experiment had a greater effect on the yield of plants in potted culture than in hydroponic culture. The differences are probably due to the different effects of the fields on the medium in which the plants were grown. A solid substrate or soil behaves differently in an electric field that does a hydroponic liquid medium. In an electrostatic field due to conductivity, part of the ions move, depending on their sign, in the direction of the appropriate electrode. In an electromagnetic field, however, a medium with a high ion content will behave like an electrical conductor. Such effects may change the nutritional circumstances of a plant.

The plants were sprayed once during the experiment: this is a routine procedure carried out for the protection of plants in all greenhouses. It should, however 
be emphasized that during the experiment exceptionally small numbers of the pest, whitefly Aleyrodidae, typical for these plants, were found on the tomatoes. The electric fields probably had an unfavorable influence on the development of this insect.

It seems that the results of this study are favorable enought to warrant their use in stimulating tomato growth, especially since no additional fertilization was used.

\section{CONCLUSIONS}

1. Electrostatic fields from 2,2 to $46,5 \mathrm{kV} / \mathrm{m}$ and broad-band electromagnetic fields of an intensity from 20 to $500 \mathrm{~V} / \mathrm{m}$ are significant factors whose effectivity dependent on intensity is manifested in growth reactions of tomatoes. Changes in the intensities of the electrostatic and electromagnetic fields are accompanied by changes in the yield of plants, their height, biomass and number of fruits.

2. The different optimal intensities of the electrostatic and electromagnetic fields inducing maximal yield stimulation as well as plant height and biomass production point to different mechanisms of their action.

3. Specific reactions of tomato plants to electrostatic and electromagnetic fields have been found. In electromagnetic fields the leaf surface is increased, while in electrostatic fields the leaves are highly lobed and have sharp contures and are very intensely green.

4. Electrostatic and electromagnetic fields of specified parameters can be used to stimulate the growth of plants under greenhouse conditions.

\section{REFERENCES}

B r a t t o n O. B., He n r y E. W., 1977. Electrical stimulation and its effects on indoleacetic acid and peroxidase level in tomato plants (Lycopersicon esculentum). J. Exp. Bot. 28: 338-344.

B r o ok s S. C.. B r o o k s M. M., 1941. The permeability of living cells. Berlin-Zehlendorf, pp. 395.

B u r $r$ H. S., 1975. The electrodynamic theory of life.[In]: Blue print in immortality. New York, pp. $322-333$.

Dąbrowski S., Grachow i z J., P ietrzyk W., 1981. Elektryczne wlaściwości nasion i ich praktyczne wykorzystanie. PAN, Zakt. Agrofiz., Lublin.; Probl. Agrofiz. 35: 1-50.

F e y n m a n R. P., L e i g h to 0 R. B., S a n d s M., 1971. Feynmana wyklady z fizyki. T. II. cz. I, PWN. Pp. 151-166.

Gumińska Z., Gracz-Nalepka M., Kukasiewicz B.. Sobolewicz E., TurkicwiczT.. 1975. Wpływ niektórych detergentów $\mathrm{i}$ humianu oraz rodzaju ściólek na plon pomidorów w uprawie hydroponicznej. Acta Agrobot. 28: 205-215.

L e m s t r ö m S., 1904. Electricity in Agriculture and Horticulture. Electrician Publishing Co, London. 
L un d E. J., 1947. Bioclectric field and growth. The University of Texas, Austin, pp. 297.

M a the s R. K., B o yd A.H.1969. Electrical properties of seeds associated with viability and vigor. ASAE 2: $778-781$.

Miller M.W., Reddy M. M., GIadys R., Yettowicz R., Kaufman G. E., 1976. Lack of effect of extremely low frequency electric and magnetic fields on roots of Vicia faba. Environ. and Experim. Botany 16: 83-88.

Miller M. W., Cartensen E. L., Robertson D., Child S. Z., 1980. $60 \mathrm{~Hz}$ electric field parameters associated with the perturbation of an eukariotic cell system. Radiat. Environ. Biophys. 18: 289-300.

Miller M. W., D o ole y D. A., Cox C., Carste n se n E. L., 1983. On the mechanism of $60 \mathrm{llz}$ electric field induced effects in Pisum sativum L. Roots. Vertical field expousers. Radiat. Environ. Biophys. 22: 293-302.

Mor $r$ is D. A., 1980. The influence of small direct electric currents on the transport of auxin in intact plants. Planta, 150: 431-434.

M u r r L. E., 1963. Plant growth response in stimulated electric field environmental. Nature 200: 490491.

Murr L. E., 1966. The biophysics of plant growth in reversed electrostatic and electromagnetic field growth in responses. Int. J. Biometeorology 10: 135-146.

N o s o l B., 1984. Przemysłowe pola elektryczne a środowisko przyrodnicze. Wrzechświat 85: 33-37.

Paw tow s k i J., 1980. Podstawowe układy elektroniczne. Wzmacniacze i generatory. WKil., W-wa, pp. 886.

R ot k i e w i c z W., 1978. Kompatybilność elektromagnetyczna w radiotechnice. WKiL, W-wa, pp. 315

S a r o s i e k J., W i e w i ó r a Z., 1986. Ecological differentiation of populations of Ricciocarpus natants and Riccia fluituns and their sensitivity on the electromagnetic radiation. 7 th Int. Symp. on Aquatic Wecds, Loughborough, U. K., pp. 291-296.

Sh a povalov L. W., Frif o nova M. F., 1979. Rozdelenie siemjan v elektronicheskom pole. Tiexnica v Selskom Xozaistvie 12: 10-12.

Th o m p k in s P.. B ir d Ch., 1975. The secret life of plants. London, pp. 430.

W i e w i ó r k a Z., 1986. Wpływ promieniowania niejonizującego na populacje Lemna minor I.. i ich ekologiczna promienjoczułość. Rozprawa doktorska. Uniwersytet Wrocławski.

Z i m m e r m a $\mathbf{n} n$ U., 1981. High frequency fusion of plant protoplasts by electric field. Planta 151: 2632.

\section{Wpływ pola elektromagnetycznego i elektrostatycznego na rozwój i plon pomidorów szklarniowych}

\section{Streszczenie}

Przedstawiono wyniki badań nad wpływem pól elektrycznych: elektromagnetycznego i elektrostatycznego na pomidory w uprawie wazonowej i uprawie hydroponicznej. Stosowane w doświadczeniu szerokopasmowe pole elektromagnetyczne o charakterze szumowym i widmie ciąglym o częstodi wości od 1 do $30 \mathrm{MHz}$ i natężeniu od $20 \mathrm{do} 500 \mathrm{~V} / \mathrm{m}$ oraz pole elek trostatyczne o natęzeniu od $2,2 \mathrm{do} 46.5 \mathrm{kV} / \mathrm{m}$ wplywa stymulująco na plonowanie pomidorów, ich wzrost i biomasę. Różnice w naturze pola elektrostatycznego i elektromagnetycznego odzwierciedlają się w różnym natężeniu optymalnym dla plonowania ponidorów. jch wzrostu. czy biomasy. Stwierdzono reakcje swoiste fromidorów na pole elektrostatyczne i elek tromagnetyczne. W polu elektrostatycznym powierzchnia liści jest pomniejszona. barwa roślin jest ciemnozielona. a ksztalt liści ostry. W polu elektromagnetycznym powierzchnia liści jest wyraźnie powiększona w porównaniu z kontrola. Pole elektromagnetyczne korzystniej wpływa na plonowanie pomidorów w uprawie wazonowej niz w uprawie hydroponicznej. Pole elektrostatyczne i elektromagnetyczne o określonych parametrach może być wykorzystywane do stymulacji wzrostu roślin w uprawie szklarniowej. 